\title{
NOTES ON THE GENUS OSMIA.
}

BY E. S. G. TITUS, UREANA, ILLINOIS.

The maxillary palpi of Osmia (sens. lat.) are given by most authors as four-jointed. I have examined the maxillary palpi of sixteen species in this group, and find in every instance that these palpi are five-jointed. The first joint is usually small, sometimes globular in shape, and visible with a hand-lens only under very favorable conditions. The following species were examined: From the coll. of the State Agr'l College of Colorado-O. armaticeps, Cr. ; Coloradensis, Cr. ; dubia, Cr. ; fulgida, Cr.; integra, Cr.; lignaria, Say, and mandibularis, Cr., all from Colorado.

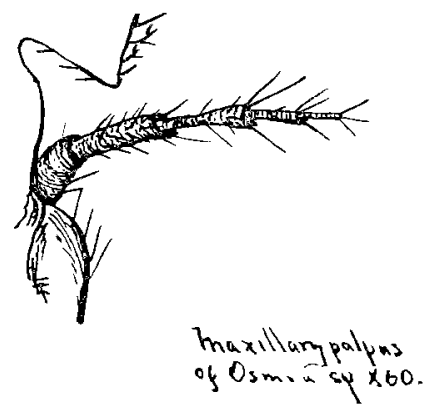

Fig, g.

From the U. S. Nat. Museum-O. abjecta, Cr. (Calif.); albiventris, Cr. (Can.) ; armaticeps, Cr. (Colo.); Californica, Cr. (Calif.) ; chalybea (Fla.) ; cobaltina, Cr. (Ia.); densa, Cr. (V. I.); distincta, Cr. (Penn.); dubia, Cr. (Colo.) ; lignaria, Say (Kans., Ga.); integra, Cr. (Colo.), and marginipennis, Cr. (La.). From the collection of Mr. Wm. H. Ashmead -O. Californica, Cr. (Wash.) ; chalybea (Wash.) ; cobaltina, Cr. (La.); distincta, Cr. (Wis.). From Ohio University-O. chalybea, Sm., and lignaria, Say; also a few other specimens from various places-O. chalybea, Sm. (N. J.) ; albiventris, Cr. (Penn.); lignaria, Say (Wis., Penn.), and megacephalus, Cr. (Penn.).

I wrote to Prof. Cockerell regarding these facts, and under date of May 20, I901, he replies: "I hasten to assure you that Osmia has 5-jointed maxillary palpi. * * * To make the thing doubly sure, my wife and $I$ just now examined the maxillary palpi of the following species. and they are all 5-jointed: O. lignaria, O. cornuta (Europe), O.phenax, O. albiventris, $O$. Kincaidii, O. brezis, $O$. calla, O. nanula." 
I am under obligations to Prof.C. P.Gillette, for the use of the material in the coll. Colo. Agr'l College; to Mr. W. H. Ashmead, for the loan of specimens from the U. S. Nat. Museum, and from his own collection; to Prof. Osborn, for specimens loaned me from Ohio University collection; and to Prof. Cockerell and Mr. W. J. Fox, for determinations and other favours.

\section{THREE NEW SPECIES OF CULICIDÆ. \\ BY D. W. COQuillett, washington, D. C.}

During his extensive investigation of the mosquitoes of this country, Dr. I. O. Howard encountered three apparently new forms, and in order that these may be referred to intelligently in his correspondence and otherwise, he has instructed the writer to name and characterize them in one of our entomological joumals. The descriptions are therefore offered herewith :

Psorophora Howardiz, new species.

Male--Head black, upper half of occiput covered with appressed white scales, except a nalrow median stripe, hairs black; first joint of antenne yellow, second joint black, its extreme base yellow, the two terminal joints black, remaincer of antennæ alternate black and whitish, the plumosity black changing to whitish at the tips ; mouth-parts black, base of third joint of palpi yellow, palpi covered with violet-purple appressed scales, the last joint narrower than the preceding, tapering to the apex, its hairs sparse and very short, the penultimate joint and apical fifth of the preceding bearing many rather long hairs; body black, the humeri yellow, pleura and sides of mesonotum bearing many appressed white scales, abdomen on upper side covered with appressed violet-purple scales, those on the first segment and a few at the hind angles of some of the other segments white; wings hyaline, first basal cell much longer than the second, petiole of first submarginal cell subequal in length to the cell; femora yellow, the apices black and on the under side fringed with rather long, narrow, nearly erect scales, remainder of femora thinly covered with appressed violaceous scales; front and middle tibiæ yellow, their apices brown, thinly covered with appressed violaceous scales, hind tibia brown, the extreme bases yeliow, covered with appressed violetpurple scales interspersed with many suberect brown ones; tarsi brown, the first joint, except its apex, and the base of the second yellow; claws 